\title{
Characteristics of Leakage Pollution of Longpan Road Gas Station and Its Enlightenment
}

\author{
Yuehua Jiang, Yun Li, Xiaojun Kang, Quanping Zhou, Xun Zhou, Yiping Zhu
}

Nanjing Center, China Geological Survey, Nanjing, China.

Email: jiangyuehua01@sina.com.cn

Received October $10^{\text {th }}, 2011$; revised November $16^{\text {th }}, 2011$; accepted December $17^{\text {th }}, 2011$

\begin{abstract}
Geological penetrating radar combined with drilling and chemical analysis has been applied to investigate leakage pollution of Longpan Road gas station in Nanjing, China. The results indicate that radar images show strong reflection anomalies along the northeast to the gas station, characterized by contaminants or contaminant plumes spreading downstream and below. The drilling results confirmed the contents of monocyclic and polycyclic aromatic hydrocarbons contained in the layers of fine sands ranging from $0.60 \mathrm{~m}$ to $6.0 \mathrm{~m}$ beneath the surface mostly exceed Chinese standard severely, such as toluene and isobutylbenzene with high content at $2738 \mu \mathrm{g} / \mathrm{kg}$ and $64,505 \mu \mathrm{g} / \mathrm{kg}$, respectively. Therefore, it is considered that geological penetrating radar can be employed to investigate leakage contamination of gas stations, and remediation and administration should be conducted in the polluted soil layers and aquifers.
\end{abstract}

Keywords: Gas Stations; Leakage Contamination; Geological Penetrating Radar; Nanjing

\section{Introduction}

Gas stations have been the major contamination sources of groundwater in the USA. More than 440,000 underground gasoline tanks had been confirmed leaking before 2001, and almost all gas stations built before the 1970s and most of gas stations built before the 1980s have been leaking [1]. Shell Oil Company declared that one third of the 1100 gas stations in Britain caused soil and groundwater contamination, while such contaminations also happened in Czech Republic, Hungary, as well as some South American countries.

Recently, leakage contamination of gas stations occurred at times in Nanjing, Beijing, Guangzhou, Shenyang, Xi'an, Chengdu and other places. Data show that leakage contamination of gas stations has been in high incidence in China.

The problem about soil and groundwater contamination from leakage of gas stations so far has not been attached adequately importance in China. In view of the growing number of large stations always located in the downtown, it is inconvenient to carry out engineering exploration and thus leakage from gas stations is entirely possible to be the largest sources for underground organic contamination in China. In addition, it is difficult to remove organic contaminants and remedy the contaminated groundwater and soil [2], and lots of organic contaminants are carcinogenic, teratogenic and mutagenic to human body and organisms after they come into the environment [3,4]. Therefore, it is necessary and important to carry out studies, such as application of GRP, on leakage contamination from underground gasoline tanks of gas stations for quick forecasting and precaution.

On July 4, 2006, underground tanks with 25t of 90 \# gasoline of Lanyan Petrochemical gas station in Longpan Road of Nanjing leaked. Gasoline not only penetrated into the nearby sewers, underground municipal pipelines of gas transportation, telecommunications and water supply, but also involved the surrounding atmosphere, soil and shallow groundwater. The leakage caused traffic interruption, and irrelevant personnel, open flame and mobile phones were not allowed to emerge in the scope of $1 \mathrm{~km}$. The police, department of environmental protection and fire departments spent 20 hours of co-operation to defuse explosive danger. As the gas station is located in the downtown, it is hard to carry out large-scale conventional drilling survey. Therefore, geological penetrating radar combined with drilling and chemical analysis has been applied to identify leakage contamination of the gas station.

\section{Application Situation of Ground Penetrating Rada}

Ground Penetrating Radar (GPR), namely electromagnetic pulse radar [5], is a high-resolution instrument with high-frequency electromagnetic waves to detect underground targets [6]. In need of detection of mines and un- 
derground tunnels, the US military played a great role in promoting the development of GPR in the mid-1960s to the early 1970 s, and since then, GPR was widely applied in detecting minerals and determining the water table, soil interface, contact faces between differential lithologies, holes in rocks, faults, bedding joint and planes [7]. Since the 1980s, the noise immunity, sampling rate and data-processing technologies of GPR have been improved greatly and applications have been extended from traditional geological survey [8] and mineral exploration [9] to the investigations of archaeology, environment, etc. At present, the GPR application mainly focuses on the survey and monitoring of the highways and tunnels in China $[10,11]$.

It was in the late 1970s that GPR technique began to be used to detect underground organic contaminants in the contaminated area [12]. Lord and Koemer [13] thought that among detection techniques used in the contaminated area, GPR was the most reliable means to detect the buried underground storage tanks and leakages, delineate boundaries and characterize the underground geological (Figures 1 and 2). Saintenoy etc. also carried out some studies on the application of GPR [12,14-18]. On the whole, few studies, however, were carried out overseas on the application of GPR in detecting under-ground organic contaminants and mostly concentrated in areas with layers of thick sandstone or ice $[19,20]$.

The application of GRP in detecting underground organic contaminants has just begun in China, and there were few documents upon such studies. Jiang Yuehua etc. recently applied GPR in the survey of leakage contamination in Guiyang Shengfu gas station located in Karst area and succeeded in the identification of spatial distribution of organic contaminants leaking from the gas station [2].
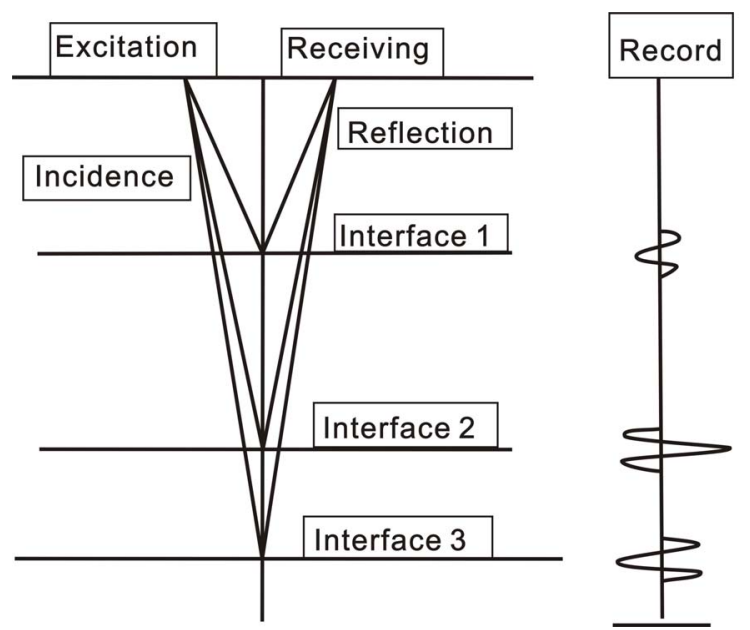

Figure 1. Sketch of technical principle of ground penetrating radar.
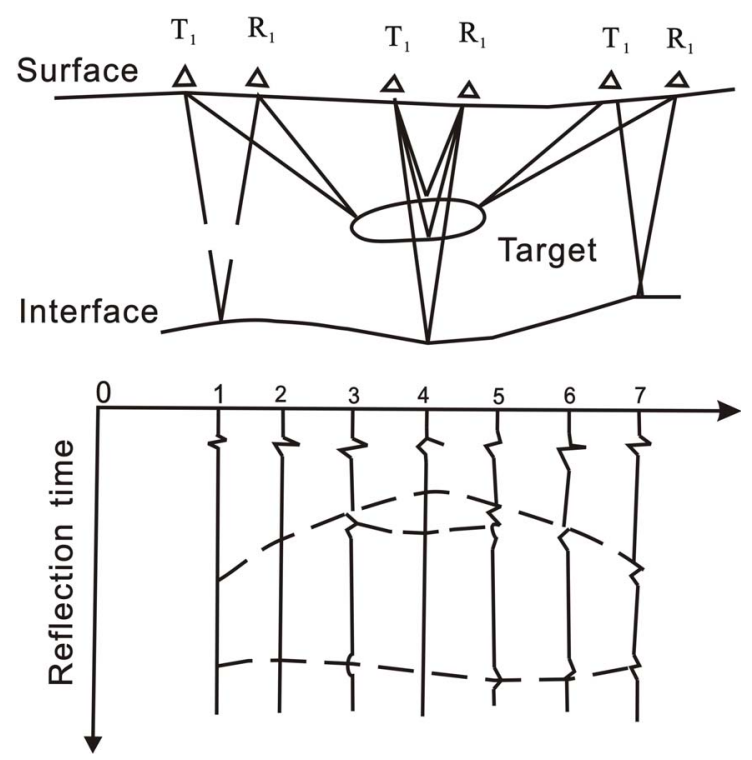

Figure 2. Sketch of waveform annal of ground penetrating radar.

\section{Methodologies}

The study and analysis on leakage contamination of the gas station have been done as follows: GPR surveyManual Drilling-Sampling and Testing-Comprehensive Studies. Manual drilling adopts Luoyang shovels.

Samples were tested with instruments such as laser plasma mass spectrometer, gas chromatography (GC), liquid chromatography (LC), gas chromatograph mass spectrometer (GC/MS), etc. at Supervision and Testing Center of East China Mineral Resources of the Ministry of Land and Resources. GPR data was obtained with one ground penetrating radar of RAMAC/GPR produced by Mara Company in Sweden and processed with Reflexw interpretation software.

\section{Results}

\subsection{Strata and Groundwater Flow}

According to the field survey combined with geomorphological and hydrogeological data, it is found that the water table around the gas station in Longpan road of Nanjing is about $2.0-2.5 \mathrm{~m}$, and groundwater flows from north to south (Figure 3).

Based on documents, the subsurface geology was found to consist of two parts. The lower part is a layer of Lower Cretaceous gabbros with the weathered residual layer about $0.3 \mathrm{~m}$ thick, and the upper one is layers of Quaternary lake sediments. Bottom-up layers of lake sediments are Middle Pleistocene brown silty clay $(2.0 \mathrm{~m}$ thick), Upper Pleistocene light gray-yellow fine sand with thin-layer silty clay ( $4.0 \mathrm{~m}$ thick), and Holocene 
gray to gray-yellow silty clay ( $0.6 \mathrm{~m}$ thick). The layer of fine sand is the main aquifer.

\subsection{GPR Data}

GPR data were collected across six traverses at this site. These lines are shown in Figure 3. as No.1 to No.6. According the GPR data, GPR images of No.1, No.4 and No. 5 profiles are characterized by obvious abnormalities with strong reflections (Figures $\mathbf{4}$ and 5), whereas it is "normal" in the others (Figure 6). The strong reflections in No.4 section are mainly shown at about 24 to 40 meters, and strong reflections almost are shown in the whole line of No.5.

As No.4 and No.5 line are down-gradient from the underground gasoline tanks and No.5 line is further than No.4 line from that, it is obvious that the range with strong reflections in No.5 line is larger than that in No.4. And lots of gasoline contaminants exuding from the soils can be seen in the sewer at the end of No.5 line. Therefore, it is concluded that the strong reflections shown in GPR images can be used to represent the distribution of contaminants. According to the characteristics of No.4 and No.5 line, contaminants and contaminant plume spread downstream and below along the groundwater flow, and the length and width of contaminant plume is at least greater than $15 \mathrm{~m}$ and ranges from $0.5 \mathrm{~m}$ to $20 \mathrm{~m}$, respectively.

\subsection{Sample Test}

After the collection of GPR data, we used one Luoyang shovel to drill one shallow bore at the end of NO.5 line. It was found that there was a strong irritant smell of gasoline in the soils at depths from $0.60 \mathrm{~m}$ to below, especially in the layer of fine sand. Two soil samples (T1, T2) have been taken at the depth of $0.80 \mathrm{~m}$ and $1.50 \mathrm{~m}$. The results indicate that contents of monocyclic aromatic hydrocarbons, polycyclic aromatic hydrocarbons and halogenated hydrocarbons in the two samples are high, and the contents of monocyclic and polycyclic aromatic hydrocarbons mostly exceed Chinese standard severely

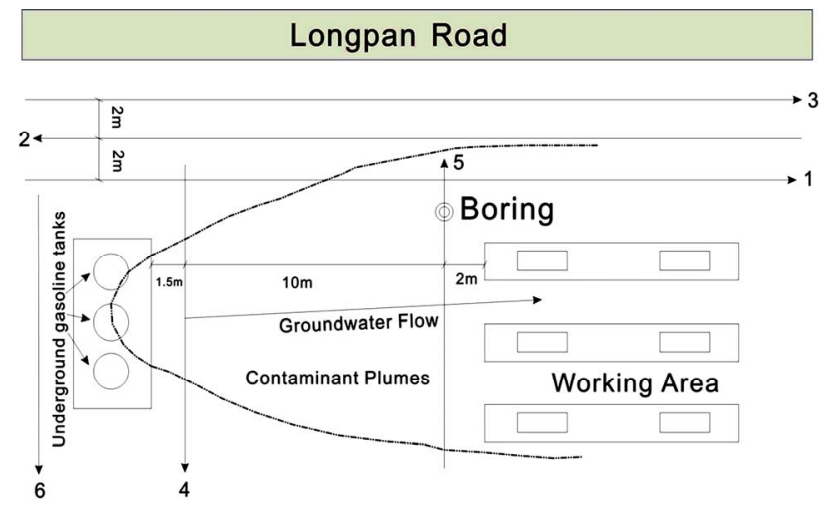

Figure 3. Underground storage tank locations and distribution of GPR lines.

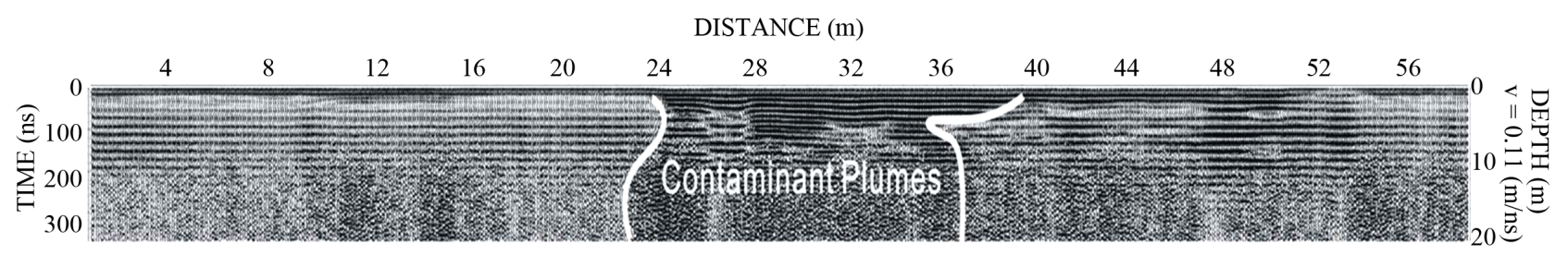

Figure 4. Characteristics of contaminant plumes in the GPR image of No.4 profile.

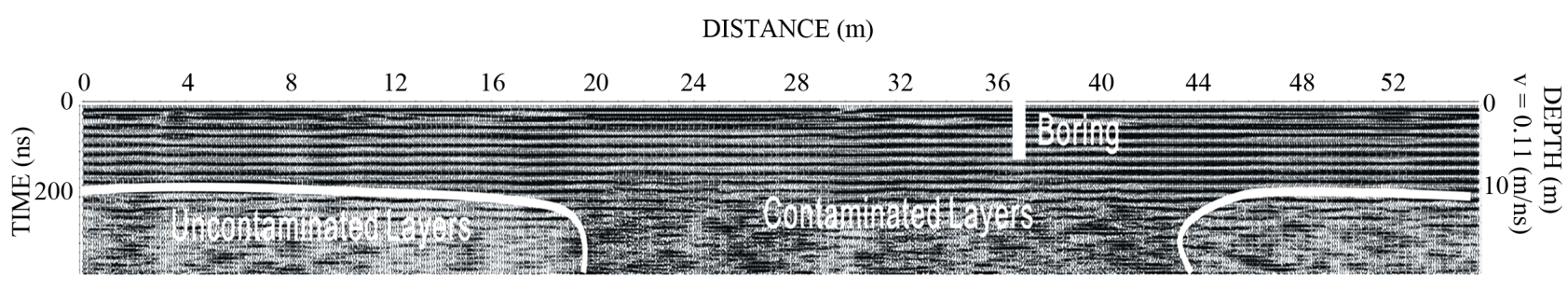

Figure 5. Characteristics of contaminant plumes in the GPR image of No.5 profile.

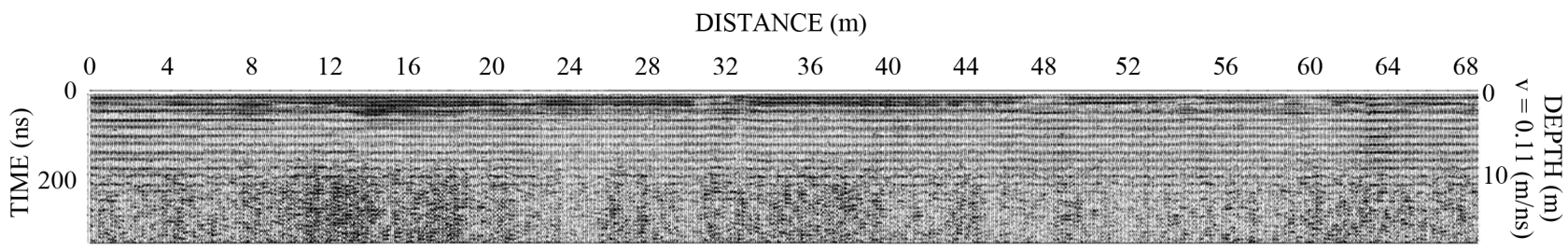

Figure 6. Characteristics of contaminant plumes in the GPR image of No.6 profile. 
(Table 1). For example, contents of toluene, ethylbenzene, $\mathrm{m}$ - + p-xylene, 1,3,5-trimethylbenzene, 1,2,4-trimethylbenzene and isobutylbenzene of $\mathrm{T} 1$ and $\mathrm{T} 2$ sample are $2738.6 \mu \mathrm{g} / \mathrm{kg}, 2569.44 \mu \mathrm{g} / \mathrm{kg}, 8516.27 \mu \mathrm{g} / \mathrm{kg}, 21929.32$ $\mu \mathrm{g} / \mathrm{kg}, \quad 61035.67 \mu \mathrm{g} / \mathrm{kg}, \quad 64505.33 \mu \mathrm{g} / \mathrm{kg}$ and 1760.53 $\mu \mathrm{g} / \mathrm{kg}, 1610.45 \mu \mathrm{g} / \mathrm{kg}, 7869.93 \mu \mathrm{g} / \mathrm{kg}, 30209.91 \mu \mathrm{g} / \mathrm{kg}$, $66934.22 \mu \mathrm{g} / \mathrm{kg}, 70033.84 \mu \mathrm{g} / \mathrm{kg}$, respectively.

Table 1. Results of soil samples taken from Longpan Road gas station.

\begin{tabular}{|c|c|c|}
\hline \multirow{2}{*}{ Organic compounds } & \multicolumn{2}{|c|}{ Contents $(\mu \mathrm{g} / \mathrm{kg})$} \\
\hline & $\mathrm{T} 1$ & $\mathrm{~T} 2$ \\
\hline 1,1-dichloroethylene & 27.40 & 8.20 \\
\hline Dichloromethane & 42.54 & 147.58 \\
\hline trans-1,2-dichloroethylene & 4.30 & 12.82 \\
\hline 1,1-dichloroethane & 17.80 & 52.06 \\
\hline cis-1, 2-dichloroethylene & 16.34 & 20.64 \\
\hline 2,2-dichloropropane & 235.18 & 192.38 \\
\hline bromochloromethane & 9.28 & 14.94 \\
\hline chloroform & 12.16 & 21.56 \\
\hline 1,1,1-trichloroethane & 49.64 & 591.34 \\
\hline 1,2-dichloroethane & 25.80 & 7.34 \\
\hline 1,1-dichloroethylene & 27.40 & 8.20 \\
\hline benzene & 30.68 & 48.42 \\
\hline trichloroethylene & 27.85 & 34.24 \\
\hline 1,2-dichloropropane & 29.15 & 17.10 \\
\hline dibromomethane & 9.00 & 12.46 \\
\hline bromo-dichloromethane & 21.08 & 15.56 \\
\hline toluene & 2738.60 & 1760.53 \\
\hline 1,1,2-trichloroethane & 135.30 & 84.72 \\
\hline tetrachloroethylene & 516.44 & 508.74 \\
\hline 1,2-dibromoethane & 25.40 & 29.57 \\
\hline ethylbenzene & 2569.44 & 1610.45 \\
\hline m- + p-xylene & 8516.27 & 7869.93 \\
\hline styrene & 261.23 & 261.16 \\
\hline O-xylene & 6281.73 & 6361.61 \\
\hline 1,1,2,2-tetrachloroethane & 434.37 & 500.75 \\
\hline cumene & 869.34 & 1132.73 \\
\hline 2-chlorotoluene & 420.90 & 24.65 \\
\hline n-propyl benzene & 3719.41 & 2114.29 \\
\hline
\end{tabular}

\section{Continued}

\begin{tabular}{lcc}
\hline 4-chlorotoluene & 4234.67 & 4466.08 \\
1,3,5-trimethylbenzene & 21929.32 & 30209.91 \\
1,2,4-trimethylbenzene & 61035.67 & 66934.22 \\
isobutylbenzene & 64505.33 & 70033.84 \\
$\rho$-cymene & 629.35 & 756.41 \\
n-Butylbenzene & 4078.35 & 4823.19 \\
naphthalene & 3233.38 & 4636.89 \\
acenaphthene & 167.22 & $<5.00$ \\
fluorene & 72.68 & 80.61 \\
phenanthrene & 430.88 & 374.71 \\
anthracene & $<5.00$ & 16.52 \\
fluoranthene & 416.24 & 834.04 \\
Pyrene & 472.64 & 1017.10 \\
benzo (a) anthracene & 185.97 & 412.76 \\
flexion( & 132.20 & 312.75 \\
benzo (b) fluoranthene & 160.45 & 394.60 \\
benzo (k) fluoranthene & 80.62 & 190.84 \\
benzo (a) pyrene & 165.43 & 388.86 \\
dibenzo (a, h) anthracene & 27.22 & 65.61 \\
benzo (g, h, i) perylene & 137.51 & 273.19 \\
\hline & & \\
& &
\end{tabular}

Therefore, comparing the results of soil samples with the reflection characteristics of GPR, it is clearly inferred that contaminants are mainly concentrated in the layer of fine sand and migrate and diffuse in this layer. The two samples taken from this layer are of high organic concentrations, corresponding to the characteristics of strong reflections in the GPR images. It reveals that soils contaminated by organic matters are shown in GPR images with strong reflections and are obviously different from the surrounding uncontaminated soils, and confirms that GPR can be used to delineate the contaminant plume boundaries and denote the direction of contaminants migration and of good practical results.

\section{Discussion and Conclusions}

1) Through the application of GPR, the range, depth and diffusive direction of the plume caused by leaking from underground gasoline tanks of Lanyan gas station in Longpan road of Nanjing have been revealed approximately. The soil samples taken from the revealed plume through drilling are of high contents of monocyclic aromatic hydrocarbons, polycyclic aromatic hydro- 
carbons and halogenated hydrocarbons, and that of monocyclic and polycyclic aromatic hydrocarbons mostly exceed Chinese standard severely. It verifies the good effects of the application of GPR in detecting the leakage contamination.

2) The study illustrates GPR can be a useful tool to help assess the extent of organic contaminant plumes, and GPR surveys can offer a non-destructive, in-situ method to supply real-time records of profiles and clear and intuitive images with high efficiency and good reproducibility. Compared with traditional methods, GPR is an economical and efficient method to detect organic contaminations in groundwater and soils. Therefore, it might be a method widely used in the field of environmental geological survey in the future, especially in the investigation of organic pollution where few GPR surveys has been applied.

3) Proposals of the site treatment

a) Pumping Treatment: It is the most widely used and mature technology which has been applied in 68 percent of the groundwater contamination sites in the United States. Contaminated groundwater was extracted from pumping wells or springs, then to remove contaminants above ground with treatment facilities. Finally, the treated water can be discharged into surface water or recharge groundwater. Thus, through designing appropriate pumping wells to intercept the whole contaminant plume, this treatment can be used to extract all contaminated groundwater and finally remedy the site.

b) Biological remediation: It is the latest method to treat organic contaminations in groundwater and soils of unsaturated zone [21]. This method is mainly based on adding nutrients which can promote bacterial growth and electron acceptors into contaminant plumes, thus to speed up the biodegradation rate and shorten the processing time.

\section{Acknowledgements}

This research is financially supported by "333 Project" of Jiangsu Province and Geological Survey Project of China Geological Survey (No.: 121201063400, 1212010634404, 1012010914006). Heartfelt thanks are due to Yuan Ping and Zhao Muhua from Nanjing Institute of Geology and Mineral Resources for their assistance.

\section{REFERENCES}

[1] US EPA, "Cleaning up the Nation'S Waste Sites: Markets and Technology Trends," Office of Solid Waste and Emergency Response (5102G) EPA 542-R-04-015, Washington DC, 2004, pp. 5-11.

[2] Y. H. Jiang, Y. F. Li, Q. P. Zhou and X. Zhou, "Pollution Status and Consideration of Groundwater and Soil in Cancer Villages," Hydrogeology and Engineering geol- ogy, Vol. 35, 2008, pp. 18-23.

[3] P. J. Squillace, M. J. Moran, W. W. Lapham, C. V. Price, R. M. Clawges and J. S. Zogorski, "Volatile Organic Compounds in Untreated Ambient Groundwater of the United States 1985-1995," Environmental Science \& Technology, Vol. 33, No. 3, 1999, pp. 4176-4187. doi: $10.1021 /$ es $990234 \mathrm{~m}$

[4] H. G. Zhu, "Drinking Water Organic Pollutant Mutagens Mutagenicity Test Comprehensive Evolution Comprehensive Index," Shanghai Environmental Sciences, Vol. 14, No. 10, 1995, pp. 44-49.

[5] D. L. Moffat and R. J. Puskar, "A Subsurface Electromagnetic Pulse Radar,” Geophysics, Vol. 41, No. 3, 1976, pp. 506-518. doi:10.1190/1.1440629

[6] R. M. Morey and W. S Harrington, "Feasibility of Electromagnetic Subsurface Profiling," EPA R2-72-082, Washington DC, 1972.

[7] M. Ferry, M. Meghraoui, J. F. Girard, T. K. Rockwell, Ö. Kozaci, S. Akyuz and A. Barka, "Ground-Penetrating Radar Investigations along the North Anatolian Fault near Izmit, Turkey: Constraints on the Right-Lateral Movement and Slip History," Geology, Vol. 32, No. 4, 2004, pp. 85-88. doi:10.1130/G19949.1

[8] J. A. Doolittle, "Using Ground-Penetrating Radar to Increase the Quality and Efficiency of Soil Surveys," In: W. U. Reybold and G. W. Petersen, Eds., Soil Survey Techniques, SSSA Special Publication No. 20, Soil Science Society of America, Madison, 1987, pp. 11-32.

[9] W. E. Pittman, R. H. Church, W. E Webb and J. T. McLendon, "Ground-Penetrating Radar: A Review of Its Application in the Mining Industry," U.S. Bureau of Mines Information Circular 8964, Alexandria 1984, p. 23.

[10] Lv. Fuxue, "Application of Geological Rradar in Investigation and Treatment of Highway Subgrade," Construction Technology, Vol. 37, 2008, pp. 150-152.

[11] X. Z. Wang, "Application Analysis of Geological Radar in Railway Tunnel Engineering Measuring," Soil Engineering and Foundation, Vol. 22, No. 3, 2008, pp. 47-58.

[12] A. K. Benson, "Applications of Ground Penetrating Radar in Assessing Some Geologic Hazards-Examples of Groundwater Contamination, Faults and Cavities," Journal of Applied Geophysics, Vol. 33, No. 6, 1995, pp. 177-193.

[13] J. A. E. Lord and R. M. Koemer, "Nondestructive Testing (NDT) Techniques to Detect Contained Subsurface Hazardous Waste," EPA/600/2-87/078, Washington DC, 1987.

[14] A. Saintenoy, S. Schneider and P. Tucholka, "Evaluating Ground Penetrating Radar Use for Water Infiltration Monitoring," Vadose Zone Journal, Vol. 7, 2008, pp. 208214. doi:10.2136/vzj2007.0132

[15] J. J. Daniels, R. Roberts and M. Vendl, "Ground Penetrating Radar for the Detection of Liquid Contaminants," Journal of Applied Geophysics, Vol. 33, No. 1-3, 1995, pp. 195-207.

[16] M. L. Brewster and A. P. Annan, "Ground-Penetrating Radar Monitoring of a Controlled DNAPL Release; 200 MHz Radar," Geophysics, Vol. 59, No. 8, 1994, pp. 1211 1221. doi:10.1190/1.1443679 
[17] M. L. King, "Locating a Subsurface Oil Leak Using Ground Penetrating Radar," Proceedings of the Eighth International Conference on Ground Penetrating Radar, Gold Coast, 23 May 2000, pp. 346-350.

[18] T. Saarenketo and T. Scullion, "Road Evaluation with Ground Penetrating Radar," Journal of Applied Geophysics, Vol. 43, No. 2-4, 2000, pp. 119-138. doi:10.1016/S0926-9851(99)00052-X

[19] M. Leopold, J. Völkel and K. Heine, "A Ground-Penetrating Radar Survey of Late Holocene Fluvial Sediments in NW Namibian River Valleys: Characterization and Comparison," Journal of the Geological Society, Vol. 163,
No. 6, 2006, pp. 923-936. doi:10.1144/0016-76492005-092

[20] J. Woodward and M. J Burke, "Applications of GroundPenetrating Radar to Glacial and Frozen Materials," Journal of Environmental \& Engineering Geophysics, Vol. 12, No. 1, 2007, pp. 69-85. doi:10.2113/JEEG12.1.69

[21] J. M. Chen, F. L. Pu, X. Chen andY. Q. Sun, "Biodegradation Technology of MTBE," Techniques and Equipment for Environmental Pollution Control, Vol. 5, No. 1, 2004, pp. 61-64. 